\begin{tabular}{|c|l|}
\hline Title & Characterization of Three Continuous Cell Lines from Marine Fish \\
\hline Author(s) & Fernandez, R. D.; Y oshimizu, M.; Kimura, T.; Ezura, Y.; Inouye, K.; Takami, I. \\
\hline Citation & $\begin{array}{l}\text { Journal of A quatic A nimal Health, 5(2), 127-136 } \\
\text { https://doi.org/10.1577/1548 8667(1993)005<0127:COTCCL }>2.3 . C 0 ; 2\end{array}$ \\
\hline Issue Date & 1993-06 \\
\hline Doc URL & http://hdl.handle.net/2115/38310 \\
\hline Type & article \\
\hline File Information & yoshimizu-119.pdf \\
\hline
\end{tabular}

Instructions for use 


\title{
Characterization of Three Continuous Cell Lines from Marine Fish
}

\author{
R. D. Fernandez, M. Yoshimizu, T. Kimura, and Y. Ezura \\ Laboratory of Microbiology, Faculty of Fisheries \\ Hokkaido University, Hakodate 041, Japan
}

\section{K. INOUYE}

National Research Institute of Aquaculture

Tamaki-cho, Watarai-gun, Mie 519-04, Japan

\section{TAKAMI}

Fisheries Experimental Station, Nagasaki Prefecture

Nobozaki, Nishi-Sonogi-gun, Nagasaki 851-05, Japan

\begin{abstract}
Three continuous cell lines were established: JSKG from gonads of Japanese striped knife jaw Oplegnathus fasciatus, KRE from embryos of a hybrid of kelp Epinephelus moara and red spotted grouper E. akaara, and PAS from the skin of greater amberjack (also called purplish amberjack) Seriola dumerili ; these cell lines were passed 60, 89, 120 times, respectively. Although initially cultured in Leibovitz's L-15 medium, two of the cell lines, JSKG and PAS, exhibited optimal growth response in Eagle's minimum essential medium buffered with a combination of tris and sodium bicarbonate. These cell lines were initiated at a higher $\mathrm{NaCl}$ concentration of $0.206 \mathrm{M}$ but gradually adapted to the low $\mathrm{NaCl}$ concentration of $0.116 \mathrm{M}$ after several subcultures. Optimum growth temperature was $25^{\circ} \mathrm{C}$ for JSKG and PAS cells, and $30^{\circ} \mathrm{C}$ for KRE cells. The modal chromosome number is 83 for the JSKG cell line, 92 for the KRE cell line, and 96 for the PAS cell line. Results for efficiency of plating indicate that all three cell lines are composed of transformed cells. Cell lines JSKG and PAS are susceptible to nine fish viruses, including channel catfish virus (CCV) and chum salmon virus (CSV). The KRE cell line is susceptible to CCV and fish rhabdoviruses of the vesiculovirus group. None of the cells showed cytopathic effect for Oncorhynchus masou virus (OMV) or Herpesvirus salmonis. Yields of infectious pancreatic necrosis virus (IPNV), infectious hematopoietic necrosis virus (IHNV), hirame rhabdovirus (HRV), and CSV were relatively low in these cell lines.
\end{abstract}

There is a growing interest in the aquaculture of marine fishes because of the high economic value of these fishes. Concomitantly, there is a high risk of viral diseases occurring in these fish species, especially in intensive marine aquaculture systems. Consequently, susceptible cell lines need to be established from marine fish for use in viral diagnostics. Since the establishment of the first fish cell line, most efforts have been concentrated on the development of cell lines from freshwater and coldwater sport and aquaculture species (Clem et al. 1961; Wolf and Quimby 1969; Wolf and Mann 1980). These cell lines are now being used in the isolation and study of economically important fish viruses.

This article describes the establishment of three cell lines derived from the gonad, embryo, or skin of three species of marine fish: Japanese striped knife jaw Oplegnathus fasciatus, a hybrid of kelp
Epinephelus moara and red spotted grouper $E$. akaara, and greater amberjack Seriola dumerili.

\section{Methods}

\section{Primary Cultures and Maintenance}

Cell lines were initiated from the gonads of Japanese striped knife jaw (JSKG cell line), embryos of a hybrid of kelp and red spotted grouper (KRE cell line), and skin of greater amberjack (also called purplish amberjack; PAS cell line), according to the methods of Wolf and Quimby (1976). Gonad tissue was aseptically removed from the donor fish; embryo and skin tissues were dipped in a $50-\mathrm{mg} / \mathrm{L}$ solution of iodophor (popidone iodine, Meiji Seika) for $15 \mathrm{~min}$. These tissues were finely minced to a size of about $1 \mathrm{~mm}^{3}$ and suspended in a phosphate-buffered saline (PBS) with $\mathrm{NaCl}$ to give a final concentration of $0.206 \mathrm{M}$, and $0.25 \%$ trypsin 
was added for digestion. The suspension was poured into a digestion flask and tissues were digested overnight at $5^{\circ} \mathrm{C}$. Undigested tissues were separated by filtration through an $80-\mu \mathrm{m}$-mesh filter. Dispersed cell suspension was centrifuged at $5^{\circ} \mathrm{C}$ for $10 \mathrm{~min}$ at $200 \times$ gravity. The pellet was resuspended by gentle addition of several milliliters of the growth medium by pipette. Cell concentration was determined with a hemacytometer and adjusted to $3.5 \times 10^{5}$ cells $/ \mathrm{mL}$ with Leibovitz's L-15 medium (GIBCO) supplemented with $20 \%$ fetal bovine serum (FBS, GIBCO). Cells were seeded into $25-\mathrm{cm}^{2}$ tissue culture flasks (Falcon) and maintained in Leibovitz's L- 15 with $20 \%$ FBS. Two antibiotics were added to the medium: 100 IU penicillin (Sigma) and $100 \mu \mathrm{g}$ streptomycin (Sigma) per milliliter. Sodium chloride in the medium was increased to obtain a concentration of $0.206 \mathrm{M}$, as recommended for establishing cell lines from marine fish (Clem et al. 1961). Primary monolayers were maintained in these media until the 10th passage, after which FBS in the medium was reduced to $10 \%$. Likewise, after several passes, $\mathrm{NaCl}$ concentration was reduced to the normal concentration used in commercial media preparations, $0.116 \mathrm{M}$.

\section{Detection of Cell Growth Response}

Estimation of appropriate physiological and culture conditions for the three marine fish cell lines was based on cell growth responses. Responses of the cells were detected by the modified microplate staining technique. This technique was done by inoculating cells at a concentration of either $1 \times 10^{5}$ or $2 \times 10^{5}$ cells $/ \mathrm{mL}$ in a 96 -well microplate (Corning). After incubation, cells were fixed with $10 \%$ formalin for $30-60 \mathrm{~min}$ then washed thoroughly. Washed cells were stained with $0.1 \%$ crystal violet for $1-2 \mathrm{~h}$, washed again, and air-dried (Nakajima et al. 1988). Absorbance of dried and stained microplates was read in a microplate spectrophotometer (Corona MTP-22) at $600 \mathrm{~nm}$.

Analysis of variance was employed in statistical evaluation of data at significance levels of $P \leq$ 0.01 and $P \leq 0.05$. Comparison of means was based on Duncan's new multiple-range test (Wakimoto et al. 1984).

\section{Growth Requirements}

Culture media.-After several passes, JSKG, $\mathrm{KRE}$, and PAS cell lines were tested for growth in three kinds of media: Eagle's minimum essential medium with Earle's salts (Eagle's MEM, GIBCO), Leibovitz's L-15 medium, and medium 199 (GIBCO). In Eagle's MEM, three buffer systems were used: sodium bicarbonate alone $(26 \mathrm{mM})$; sodium bicarbonate $(8.9 \mathrm{mM})$ with tris $(16 \mathrm{mM})$; and sodium bicarbonate $(8.9 \mathrm{mM})$ with HEPES (14 mM). All media were supplemented with $10 \%$ FBS and antibiotics (100 IU penicillin and $100 \mu \mathrm{g}$ streptomycin per milliliter of the medium). After the initial seeding $\left(1 \times 10^{5}\right.$ or $2 \times 10^{5}$ cells $\left./ \mathrm{mL}\right)$, all cell lines were incubated for $7 \mathrm{~d}$ at $20^{\circ} \mathrm{C}$.

Temperature. -Optimum temperatures for growth of JSKG, KRE, and PAS cells were also determined. Cells were incubated at temperatures of $10,15,20,25,30,35$, and $40^{\circ} \mathrm{C}$ for $7 \mathrm{~d}$. Medium for this experiment was chosen on the basis of results from the above experiment on suitability of culture media. Initial cell concentrations were the same as in the culture media test.

Sodium chloride. -Growth response of the fish cell lines to $\mathrm{NaCl}$ concentrations of $0.116,0.171$, $0.256,0.341$, and $0.512 \mathrm{M}$ were likewise observed. Eagle's MEM buffered with sodium bicarbonate and tris was adjusted to each of the above salt concentrations and used as growth medium for this test. Cells were incubated at $20^{\circ} \mathrm{C}$ for $7 \mathrm{~d}$.

\section{Chromosome Counts}

Chromosome counts were determined for JSKG, KRE, and PAS cells at passage levels 57, 86, and 118 , respectively. Semiconfluent and actively growing monolayer cultures of these cells, propagated for $24 \mathrm{~h}$, were used. Chromosome counts were done according to the method of Earley (1975).

\section{Plating Efficiency}

Efficiencies of plating of JSKG, KRE, and PAS cell lines were determined at passage levels 57,85 , and 119 , respectively. The ability of the cells to form colonies were determined after $15 \mathrm{~d}$ by the methods of Fryer et al. (1981). Epithelioma papulosum cyprini (EPC) cells, an established cell line from common carp Cyprinus carpio (Fijan et al. 1983), was used as the control.

\section{Cytopathic Effects and Viral Replication}

Cytopathic effects (CPE) in JSKG, KRE, and PAS cell lines were determined after infection with 11 fish viruses (Table 1). Stocks of the virus were prepared in chinook salmon embryo (CHSE-214) cells (Lannan et al. 1984), EPC cells, rainbow trout gonad (RTG-2) cells (Wolf and Quimby 1962), or 
TABLE 1.-Fish viruses used for the production of cytopathic effect in JSKG, KRE, and PAS cell lines.

\begin{tabular}{|c|c|c|}
\hline Virus & $\begin{array}{l}\text { Abbreviation } \\
\text { (and virus type) }\end{array}$ & Source (or original reference) ${ }^{\mathrm{a}}$ \\
\hline Channel catfish virus & $\mathrm{CCV}$ & J. A. Plumb, Auburn University, Alabama \\
\hline Chum salmon virus & CSV & Winton et al. (1981) \\
\hline Eel virus of America & EVA & T. Sano, Tokyo University of Fisheries, Tokyo \\
\hline Eel virus of Europe $X$ & EVEX & T. Sano \\
\hline Herpesvirus salmonis & H. salmonis & $\begin{array}{l}\text { K. Wolf, National Fish Health Research } \\
\text { Laboratory, Kearneysville, West Virginia }\end{array}$ \\
\hline Hirame rhabdovirus & HRV & Kimura et al. (1986) \\
\hline \multirow[t]{2}{*}{ Infectious hematopoietic necrosis virus } & IHNV NAV & $\begin{array}{l}\text { J. R. Winton, National Fisheries Research Center, } \\
\text { Seattle, Washington }\end{array}$ \\
\hline & IHNV ChAb & Yoshimizu et al. (1989) \\
\hline \multirow[t]{2}{*}{ Infectious pancreatic necrosis virus } & IPNV VR 299 & K. Wolf \\
\hline & IPNV $\mathrm{Ab}$ & K. Wolf \\
\hline Oncorhynchus masou virus & OMV & Kimura et al. (1981) \\
\hline Pike fry rhabdovirus & PFRV & $\begin{array}{l}\text { B. J. Hill, Fish Disease Laboratory, } \\
\text { Weymouth, UK }\end{array}$ \\
\hline Spring viremia of carp virus & SVCV & B. J. Hill \\
\hline
\end{tabular}

a If the author of the original reference was also the source, the reference is noted.

channel catfish ovary (CCO) cells (Bowser and Plumb 1980a), and each virus was inoculated at a multiplicity of infection of 0.01 into two wells for each of the three marine fish cell lines in 24well plates. Cell lines KRE, JSKG, and PAS were observed for CPE for at least 2 weeks. The CPE produced in these marine cell lines were compared with those produced in three freshwater fish cell lines: eel ovary (EO-2) cells (Chen and Kou 1981), fathead minnow (FHM) cells (Gravell and Malsberger 1965), and EPC cells.

Cell lines that developed CPE for IPNV VR299, IHNV ChAb, HRV, CSV, OMV, or H. salmonis were further tested for virus replication efficiency. Stocks of virus were prepared in either CHSE-214, EPC, or RTG-2 cell lines, and virus concentrations were determined by assay for $50 \%$ tissue culture infective dose (TCID50/mL; Reed and Muench 1938). Each virus was inoculated (multiplicity of infection $=0.01$ ) into a monolayer of JSKG, KRE, and PAS in a $25-\mathrm{cm}^{2}$ tissue culture flask; each virus-cell line combination was prepared in duplicate. To allow absorption of the virus, flasks were incubated for $1 \mathrm{~h}$ at $15^{\circ} \mathrm{C}$, except for those with $\mathrm{CCV}$, which were incubated at $20^{\circ} \mathrm{C}$. Thereafter, except for cell lines inoculated with $H$. salmonis and $\mathrm{CCV}$, all samples were incubated at $15^{\circ} \mathrm{C}$; the samples with $\mathrm{H}$. salmonis were incubated at $10^{\circ} \mathrm{C}$, and those with $\mathrm{CCV}$ were incubated at $20^{\circ} \mathrm{C}$. After a determined number of days, 100 $\mu \mathrm{L}$ from each flask were pooled for each duplicate set of flasks, and samples were assayed for virus titers (TCID50/mL).

\section{Results}

\section{Primary Cultures and Morphology}

Primary monolayer cells were obtained from the gonad, embryo, or skin of the three species of marine fish (Table 2) and all are confirmed as epithelioid cells (Figure 1).

\section{Growth Requirements}

Culture media. - Growth responses of the three cell lines to three kinds of media and three buffer systems in Eagle's MEM were evaluated. The JSKG and PAS cell lines showed significantly higher $(P<0.05)$ absorbance readings in Eagle's MEM buffered with a combination of tris and sodium bicarbonate (Figure 2) than in other culture media. The KRE cell line showed a significantly higher $(P<0.05)$ absorbance reading in Leibovitz's L-15 medium.

Temperature.-The KRE and PAS cell lines generally exhibited a wide range of temperature tolerance from 15 to $30^{\circ} \mathrm{C}$; optimum growth was

TABLE 2.-Origin and morphology of the new cell lines from marine fish.

\begin{tabular}{llll}
\hline $\begin{array}{c}\text { Cell } \\
\text { line }\end{array}$ & \multicolumn{1}{c}{ Species } & $\begin{array}{c}\text { Tissue of } \\
\text { origin }\end{array}$ & Morphology \\
\hline JSKG & $\begin{array}{l}\text { Japanese striped knife jaw } \\
\text { KRE }\end{array}$ & $\begin{array}{c}\text { Gonad } \\
\text { Hybrid of kelp } \\
\text { and red spotted grouper }\end{array}$ & $\begin{array}{c}\text { Epithelioid } \\
\text { Epithelioid }\end{array}$ \\
PAS & $\begin{array}{c}\text { Greater amberjack } \\
\text { (=purplish amberjack) }\end{array}$ & Skin & Epithelioid \\
\hline
\end{tabular}



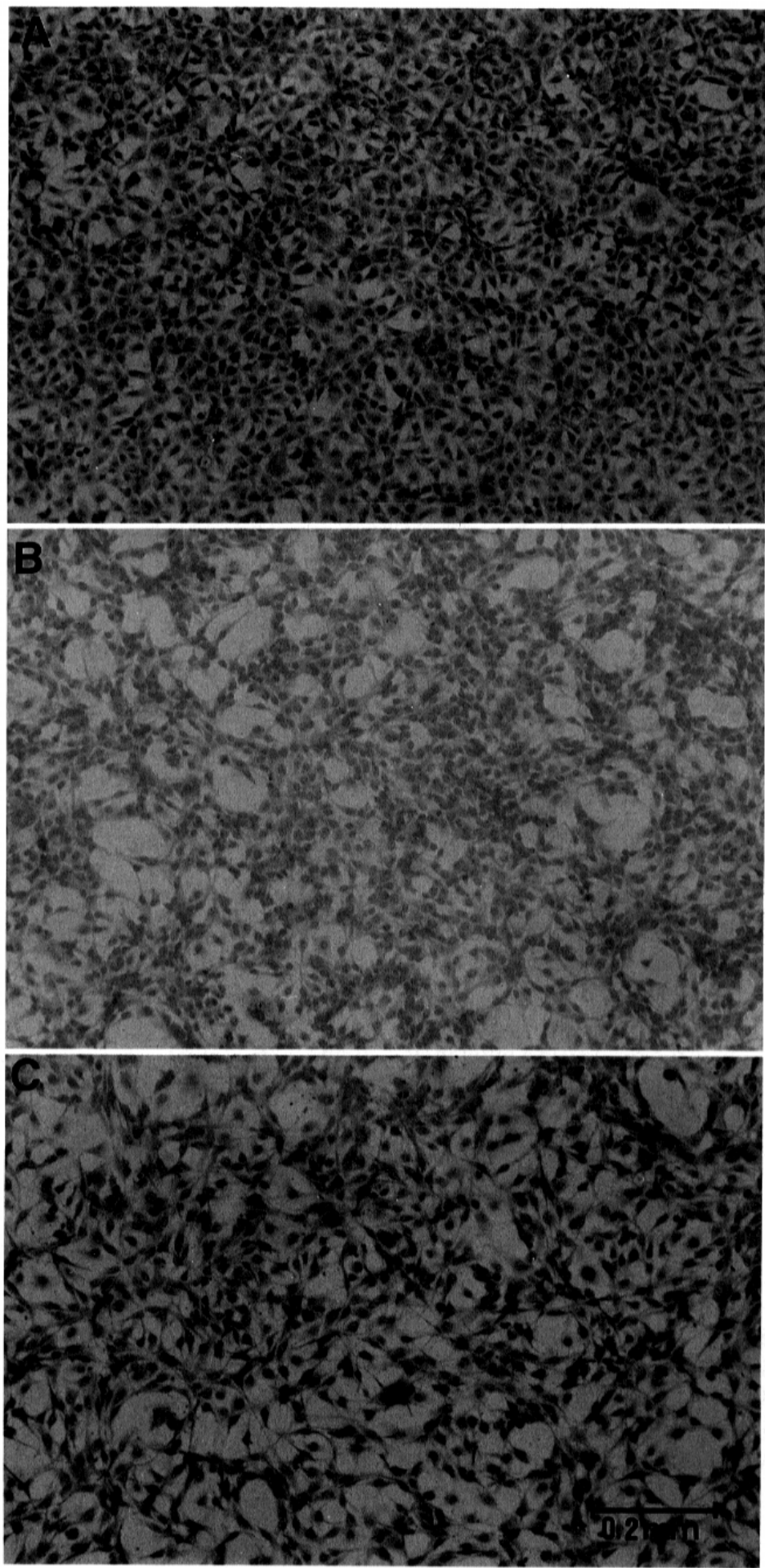

FIGURE 1.-Monolayers of three new cell lines from marine fish: (A) JSKG; (B) KRE; (C) PAS. 


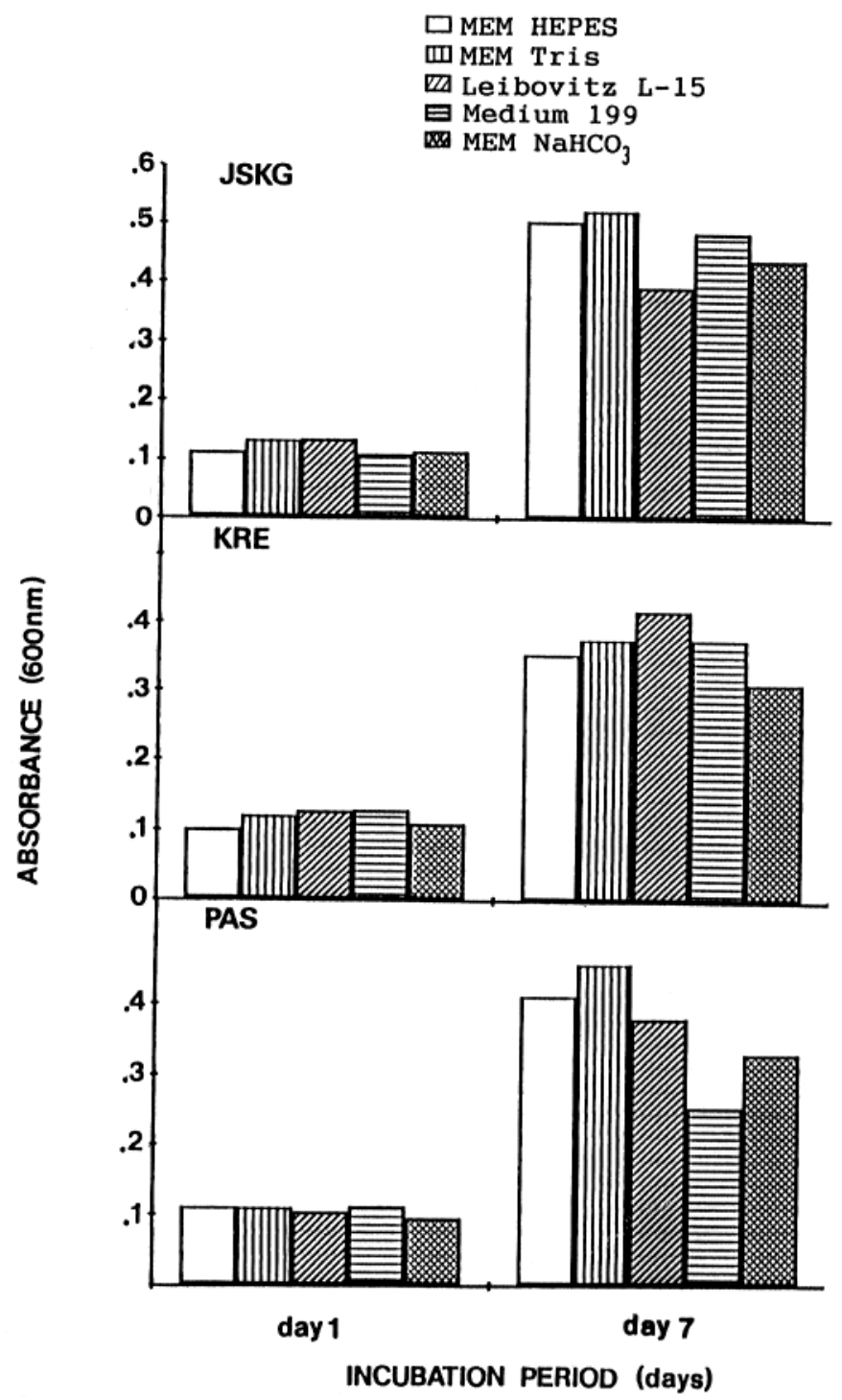

FIGURE 2.-Growth responses of JSKG, KRE, and PAS cell lines in various media. The buffer systems with Eagle's minimum essential medium with Earle's salts (MEM) are abbreviated here as follows: MEM HEPES = MEM with sodium bicarbonate and HEPES; MEM Tris = MEM with sodium bicarbonate and tris; and MEM $\mathrm{NaHCO}_{3}=$ MEM with sodium bicarbonate alone.

at $30^{\circ} \mathrm{C}$ for the $\mathrm{KRE}$ cell line and at $25^{\circ} \mathrm{C}$ for the PAS cell line. Neither of these cell lines could tolerate 35 or $40^{\circ} \mathrm{C}$. Although the JSKG cell line grew optimally at almost the same temperature as the PAS cell line, JSKG cells could not tolerate $30^{\circ} \mathrm{C}$ whereas PAS cells could (Figure 3).

Sodium chloride. - The growth of JSKG and PAS cell lines was inversely proportional to increasing $\mathrm{NaCl}$ concentration in the medium (Figure 4). Growth was significantly higher $(P<0.05)$ at the lowest $\mathrm{NaCl}$ concentration $(0.116 \mathrm{M})$, the usual concentration used in commercial media preparations. Highest growth response for KRE cells was attained by using an $\mathrm{NaCl}$ concentration of $0.171 \mathrm{M}$.

\section{Chromosome Counts}

All three cell lines were heteroploid and consisted mostly of $4 \mathrm{n}$ cells (Table 3 ). The diploid number of the Japanese striped knife jaw, the hybrid of kelp and red spotted grouper, and the greater amberjack is 48 (Ojima 1983). In 71 ran- 


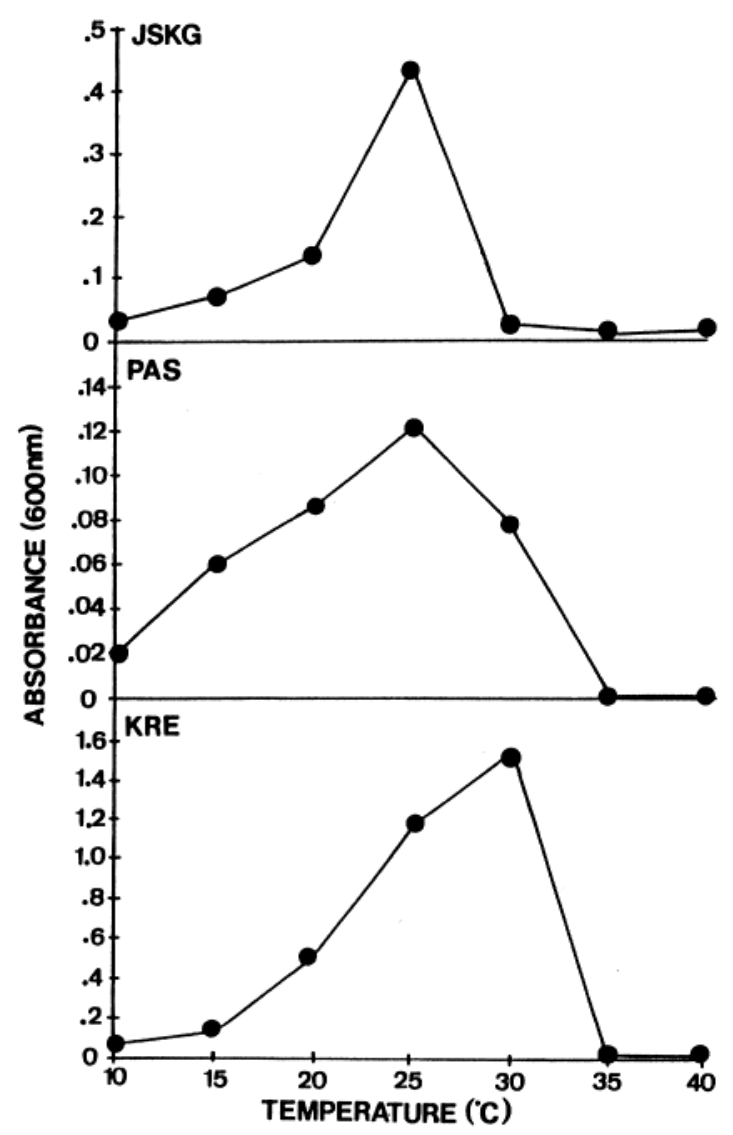

FIGURE 3.-Growth responses of JSKG, PAS, and KRE cell lines to various temperatures.

domly selected cells of the JSKG cell line, the counted chromosome number ranged from 72 to 97 , and the modal number was 83 ; in the KRE cells $(N=63)$ the chromosome number ranged from 84 to 111 , and the modal number was 92 ; in the PAS cells $(N=73)$ the chromosome number ranged from 60 to 108 , and the modal number was 96 (Table 3; Figure 5). Chromosomes of these cells were mostly metacentric.

\section{Plating Efficiency}

The plating efficiencies of the three new cell lines were compared with the plating efficiency of the EPC cell line. Plating efficiencies of the tested cell lines were relatively high and were comparable to those of EPC cells (Table 4). These results suggest that JSKG, KRE, and PAS are composed of transformed cells.

\section{Cytopathic Effect and Viral Replication}

Development of CPE in JSKG, KRE, and PAS cell lines after inoculation with 11 fish viruses is
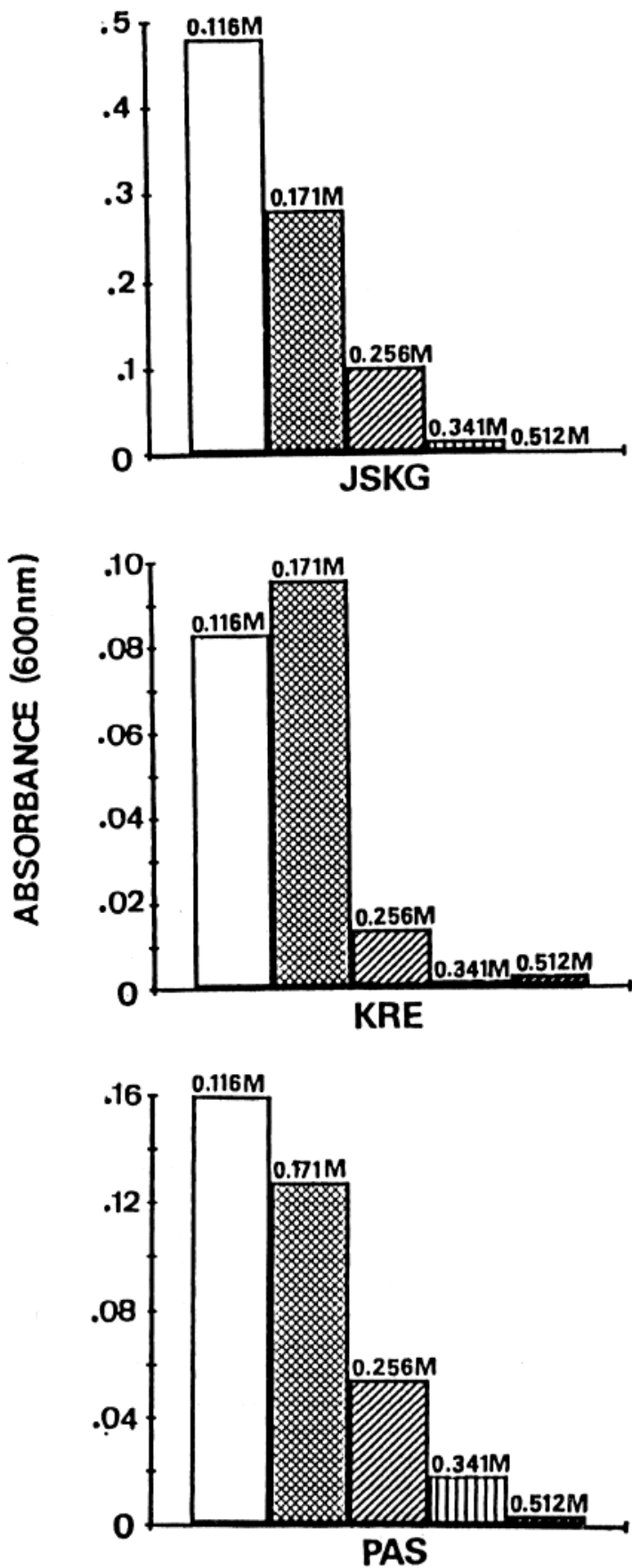

FIGURE 4.-Growth responses of JSKG, KRE, and PAS cell lines to various $\mathrm{NaCl}$ molarities in the media.

presented in Table 5; for comparison, data of this type are also presented for three common freshwater fish cell lines. The JSKG and PAS cell lines supported replication of most of these viruses. None of these cell lines developed CPE after in- 
TABLE 3.-Modal chromosome numbers of the new cell lines from marine fish.

\begin{tabular}{ccc}
\hline $\begin{array}{c}\text { Cell line } \\
\text { (pass number) }\end{array}$ & \multicolumn{1}{c}{$\begin{array}{c}\text { Species of origin } \\
\text { (diploid number) }^{\mathrm{a}}\end{array}$} & $\begin{array}{c}\text { Modal } \\
\text { chromo- } \\
\text { some } \\
\text { number }\end{array}$ \\
\hline JSKG (57) & $\begin{array}{c}\text { Japanese striped knife } \\
\text { jaw }(2 \mathrm{n}=48)\end{array}$ & 83 \\
KRE (86) & $\begin{array}{c}\text { Hybrid of kelp and red spotted } \\
\text { grouper }(2 \mathrm{n}=48)\end{array}$ & 92 \\
PAS (118) & $\begin{array}{c}\text { Greater amberjack } \\
\text { (=purplish amberjack) }(2 \mathrm{n}=48)\end{array}$ & 96 \\
\hline
\end{tabular}

a Ojima (1983).

oculation with two herpesviruses, OMV and $H$. salmonis. On the other hand, another herpesvirus, $\mathrm{CCV}$, produced CPE in all three cell lines. The KRE cell line was susceptible only to fish rhabdoviruses belonging to the vesiculovirus group. Relatively low titers of IPNV VR299 and IHNV $\mathrm{ChAb}$ were observed in tested cell lines (Table 6; Figure 6). In the JSKG and PAS cell lines, CSV was initially detected $15 \mathrm{~d}$ after inoculation (Table 6) and CSV titers increased until day 23 . The viral inoculum might have been too low to produce an immediately noticeable CPE.

\section{Discussion}

In this article we have described the establishment of three continuous cell lines from commercially important marine fishes. Since the 1980 s, several cell lines from marine fish had been reported (Table 7). Although growth was initiated in Leibovitz's L-15 medium, growth responses of JSKG and PAS cell lines were higher in Eagle's MEM buffered with a combination of tris and sodium bicarbonate. Nicholson et al. (1987) reported the use of Eagle's MEM in the establishment of cell lines from Japanese seaperch Lateolabrax

TABle 4. - Plating efficiencies for the new marine fish cell lines and a freshwater fish cell line (EPC).

\begin{tabular}{lccc}
\hline Cell line & $\begin{array}{c}\text { Cells seeded/ } \\
\text { 25-cm }\end{array}$ flask & $\begin{array}{c}\text { Average } \\
\text { number } \\
\text { of cell colonies }\end{array}$ & $\begin{array}{c}\text { Efficiency of } \\
\text { plating }(\%)^{\mathrm{a}}\end{array}$ \\
\hline EPC & $10^{3}$ & 220 & 22.0 \\
JSKG & $10^{2}$ & 23 & 23.0 \\
& $10^{3}$ & 110 & 11.0 \\
KRE & $10^{2}$ & 7 & 7.0 \\
& $10^{3}$ & 298 & 29.8 \\
PAS & $10^{2}$ & 23 & 23.0 \\
& $10^{3}$ & 176 & 17.6 \\
\hline
\end{tabular}

a (Number of cell colonies/cells seeded) $\times 100$. japonicus and a grouper, Epinephelus amblycephalus.

Clem et al. (1961) revealed the beneficial effects of higher $\mathrm{NaCl}$ concentrations in initiating cell lines from marine fish species by the trypsinization method. Use of higher $\mathrm{NaCl}$ concentrations led to the successful propagation of the grunt fin (GF) cell line. For a cell line from yellowtail scad (also called omaka) Caranx mate, osmolarity was not a critical factor (Lee and Loh 1975) and the cells were successfully subcultured at normal $\mathrm{NaCl}$
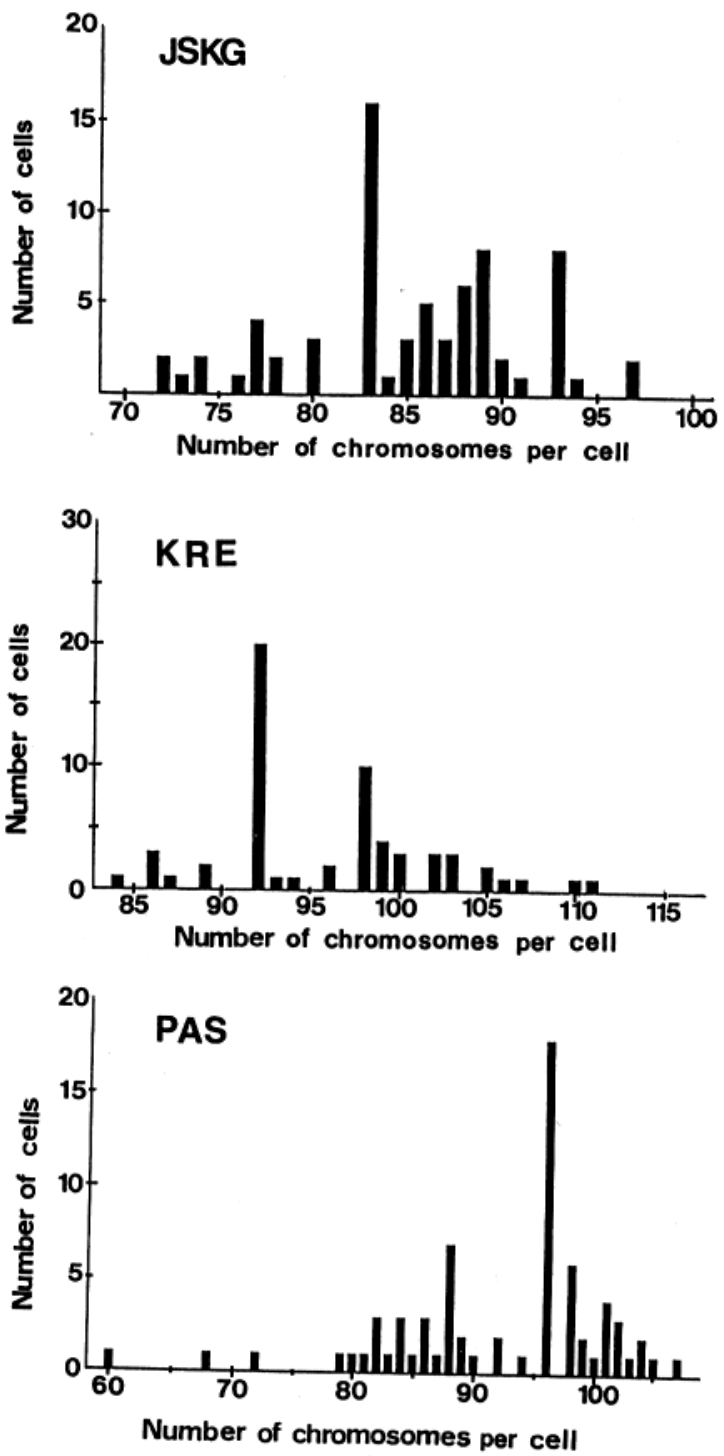

FIGURE 5.-Frequency distributions of chromosomes of the three cell lines from marine fish: JSKG at passage $57(N=71$ cells $), \mathrm{KRE}$ at passage $86(N=63$ cells $)$, and PAS at passage $118(N=73$ cells $)$. 
TABLE 5.-Development of cytopathic effect in the new marine fish cell lines and in freshwater fish cell lines after infection with 11 fish viruses. Virus acronyms are defined in Table 1.

\begin{tabular}{lcccccccc}
\hline & \multicolumn{3}{c}{$\begin{array}{c}\text { Cell lines from } \\
\text { marine fish }\end{array}$} & & & \multicolumn{3}{c}{$\begin{array}{c}\text { Cell lines from } \\
\text { freshwater fish }\end{array}$} \\
\cline { 2 - 4 } \multicolumn{1}{c}{ Virus } & JSKG & KRE & PAS & & EO-2 & FHM & EPC \\
\hline IPNV VR299 & + & - & + & & + & - & + \\
IPNV Ab & + & + & + & & + & - & + \\
IHNV NAV & - & - & + & & + & + & + \\
IHNV ChAb & + & - & + & & + & + & + \\
HRV & + & - & + & & + & + & + \\
SVCV & + & + & + & & + & + & + \\
EVA & + & + & + & & + & + & + \\
EVEX & + & + & + & & + & + & + \\
PFRV & + & + & + & & + & + & + \\
OMV & - & - & - & & - & - & - \\
H. salmonis & - & - & - & & - & - & - \\
CCV & + & + & + & & - & - & - \\
CSV & + & - & + & & + & - & - \\
\hline
\end{tabular}

concentration of $0.137 \mathrm{M}$. Likewise, Nicholson et al. (1987) and Meguro et al. (1991) reported the establishment of marine fish cell lines without additional $\mathrm{NaCl}$ in the medium. In the establishment of the three cell lines in the present study, higher $\mathrm{NaCl}$ was used during primary propagation; however, increased levels of $\mathrm{NaCl}$ in the medium were not necessary in the successive transfers, and the cells adapted readily to the usual $\mathrm{NaCl}$ concentration used in commercial media preparations.

One of the advantages of cell lines that grow at a wide temperature range is their potential suitability for isolation of both warmwater and coldwater fish viruses (Nicholson et al. 1987). All three cell lines were able to grow at temperatures from $15^{\circ} \mathrm{C}$ up to 25 or $30^{\circ} \mathrm{C}$ and were also sensitive to viruses with optimum replication at $15^{\circ} \mathrm{C}$. Likewise, the versatility of these new marine fish cell lines is evidenced by their ability to replicate CCV, which is a highly cell-specific virus, and a reovirus from chum salmon, CSV (Winton et al. 1981). $\mathrm{CCV}$ is known to replicate only in cell lines from ictalurid and related siluroid species such as brown
TABLE 7.-Marine fish cell lines established since the 1980s.

\begin{tabular}{|c|c|c|}
\hline Cell line & $\begin{array}{l}\text { Common name } \\
\text { and tissue }\end{array}$ & Original reference \\
\hline BGF & Banded grouper fin & Chen and Kou (1988) \\
\hline BGK & Banded grouper kidney & Chen and Kou (1988) \\
\hline BPK & Black porgy kidney & Tung et al. (1991) \\
\hline BPS-1 & Black porgy spleen & Tung et al. (1991) \\
\hline BPS-4 & Black porgy spleen & Tung et al. (1991) \\
\hline FF-11 & Japanese flounder fin & Meguro et al. (1991) \\
\hline GK & Grouper kidney & Nicholson et al. (1987) \\
\hline HF-1 & Japanese flounder fin & Yoshimizu et al. (1988) \\
\hline JF & Jarbua fin & Wen et al. (1990) \\
\hline PH & Perch heart & Nicholson et al. (1987) \\
\hline PL & Perch liver & Nicholson et al. (1987) \\
\hline RSBF & Red sea bream fry & Watanabe et al. (1981) \\
\hline RSF & Red snapper fin & Yoshimizu et al. (1988) \\
\hline SBF & Sea bass fin & Yoshimizu et al. (1988) \\
\hline SBK & Sea bass kidney & Watanabe et al. (1981) \\
\hline SBK & Sea bream kidney & Yoshimizu et al. (1988) \\
\hline YTK & Yellow tail kidney & Watanabe et al. (1981) \\
\hline
\end{tabular}

bullhead (BB), channel catfish ovary (CCO), and walking catfish kidney $(\mathrm{K} 1 \mathrm{~K})$ cells, at high temperatures (i.e., $25-30^{\circ} \mathrm{C}$; Bowser and Plumb 1980b; Wolf 1988). The JSKG and PAS cell lines produced initially low titers for CSV. These titers were not detectable until day 15 after inoculation, but they increased continuously until day 23 of incubation. Yoshimizu et al. (1988) reported replication of CSV in nonsalmonid freshwater fish cell lines. Studies conducted by Winton et al. (1981) showed replication of CSV at various degrees of CPE and moderate levels of virus titers in nonsalmonid lines. This article is probably the first report of CSV replication in marine fish cell lines. None of the three cell lines was able to replicate OMV and $H$. salmonis. Both of these viruses are known to replicate only in salmonid cell lines (Yoshimizu et al. 1988).

Cell lines JSKG, KRE, and PAS were passed 60,89 , and 120 times, respectively, and chromosome counts revealed that these cell lines mostly consist of $4 n$ cells. Moreover, plating efficiencies of the three cell lines that were established in this study suggest that all are composed of transformed

TABLE 6.-Viral titers $\left(\log _{10}\right.$ TCID50/mL) produced in JSKG and PAS cell lines after different incubation times. No detectable cytopathic effect of any of these viruses was found in the KRE cell line. Virus acronyms are defined in Table 1. A viral titer of at least 1.5 was required for detection.

\begin{tabular}{|c|c|c|c|c|c|c|c|c|c|c|c|c|c|}
\hline \multirow{2}{*}{$\begin{array}{l}\text { Cell } \\
\text { line }\end{array}$} & \multicolumn{3}{|c|}{ IPNV VR299 } & \multicolumn{3}{|c|}{ IHNV ChAb } & \multicolumn{3}{|c|}{ HRV } & \multicolumn{4}{|c|}{ CSV } \\
\hline & $3 \mathrm{~d}$ & $7 \mathrm{~d}$ & $15 \mathrm{~d}$ & $3 \mathrm{~d}$ & $7 \mathrm{~d}$ & $15 \mathrm{~d}$ & $3 \mathrm{~d}$ & $7 d$ & $15 \mathrm{~d}$ & $3 \mathrm{~d}$ & $7 \mathrm{~d}$ & $15 \mathrm{~d}$ & $23 \mathrm{~d}$ \\
\hline JSKG & $<1.5$ & 2.0 & $<1.5$ & 2.0 & 2.5 & 2.8 & 1.5 & 2.8 & 3.8 & $<1.5$ & $<1.5$ & 3.8 & 4.3 \\
\hline PAS & 1.5 & $<1.5$ & $<1.5$ & 2.3 & 2.8 & 5.0 & 2.0 & 4.0 & 4.8 & $<1.5$ & $<1.5$ & 3.5 & 5.5 \\
\hline
\end{tabular}



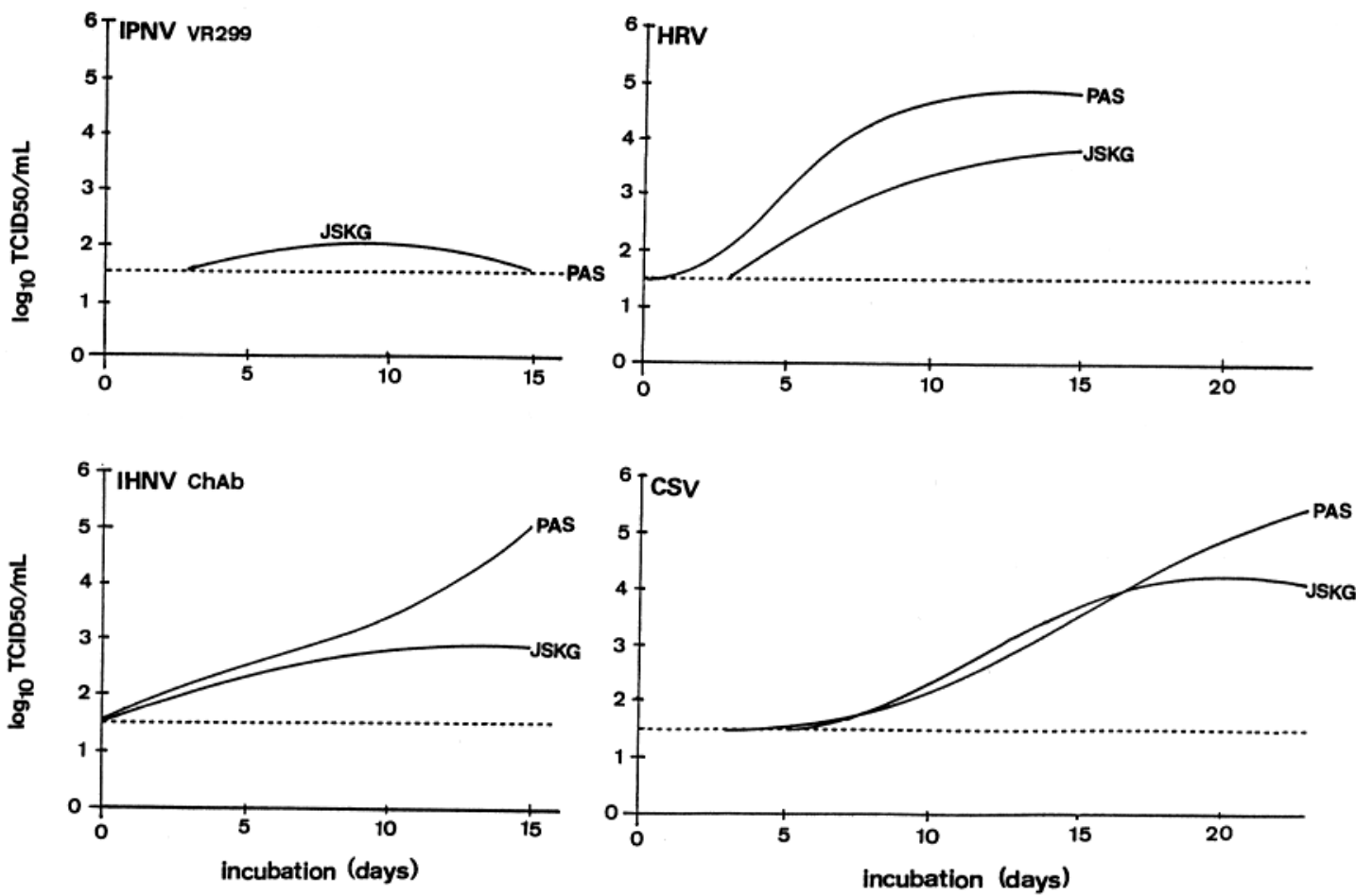

FIGURE 6.- Titers for four fish viruses incubated in JSKG and PAS cell lines. Virus acronyms are defined in Table 1. Dashed horizontal line denotes the threshold line for detection (virus titer of at least 1.5).

cells. Transformed cells are capable of growing from a dilute inoculum (Paul 1972), whereas nontransformed cells can form colonies with frequencies of only $0.1-2 \%$ after seeding at low densities (Fryer et al. 1981). Also it was reported that transformed mammalian cells are capable of producing clones of cells at high efficiency when seeded at very low densities in MEM-10 medium. Based on the above findings, the three marine fish cell lines that were established here can be considered as permanent lines. These cell lines were derived from marine species that are of economic importance, especially in Japan. Because these lines offer a wide range of susceptibility to most well-known virulent fish viruses, they can be useful tools in studying undetected viruses in marine species.

\section{References}

Bowser, P. R., and J. A. Plumb. 1980a. Fish cell lines: establishment of a line from ovaries of channel catfish. In Vitro (Rockville) 16:365-368.

Bowser, P. R., and J. A. Plumb. 1980b. Growth rates of a new cell line from channel catfish ovary and channel catfish virus replication at different temperatures. Canadian Journal of Fisheries and Aquatic Sciences 37:871-873.
Chen, S. N., and G. H. Kou. 1981. A cell line derived from Japanese eel (Anguilla japonica) ovary. Fish Pathology 16:129-137.

Chen, S. N., and G. H. Kou. 1988. Establishment, characterization and application of 14 cell lines from warmwater fish. Pages 218-227 in Y. Kuroda, E. Kurstak, and K. Maramorosch, editors. Invertebrate and fish tissue culture. Japan Scientific Societies Press, Tokyo. (Also Springer-Verlag, Berlin.)

Clem, L. W., L. Moewus, and M. M. Sigel. 1961. Studies with cells from marine fish in tissue culture. Proceedings of the Society for Experimental Biology and Medicine 108:762-766.

Earley, E. M. 1975. Chromosome preparations from monolayer cell cultures. Tissue Culture Association Manual 1:31-35.

Fijan, N., and seven coauthors. 1983. Some properties of the epithelioma papulosum cyprini (EPC) cell line from carp Cyprinus carpio. Annales de Virologie (Paris) 134E:207-220.

Fryer, J. L., B. B. McCain, and J. C. Leong. 1981. A cell line derived from rainbow trout (Salmo gairdneri) hepatoma. Fish Pathology 15:193-200.

Gravell, M., and R. G. Malsberger. 1965. A permanent cell line from the fathead minnow (Pimephales promelas). Annals of the New York Academy of Sciences 126:555-565.

Kimura, T., M. Yoshimizu, and S. Gorie. 1986. A new rhabdovirus isolated in Japan from cultured hirame (Japanese flounder) Paralichthys olivaceus and ayu 
(Plecoglossus altivelis). Diseases of Aquatic Organisms 1:207-217.

Kimura, T., M. Yoshimizu, M. Tanaka, and H. Sannohe. 1981. Studies on a new virus (OMV) from Oncorhynchus masou. I. Characteristics and pathogenicity. Fish Pathology 15:143-147.

Lannan, C. N., J. R. Winton, and J. L. Fryer. 1984. Fish cell lines: establishment and characterization. In Vitro (Rockville) 20:671-676.

Lee, M. H., and P. C. Loh. 1975. Some properties of an established fish cell line from the marine fish Caranx mate (Omaka) (38970). Proceedings of the Society for Experimental Biology and Medicine 150: 40-48.

Meguro, Y., T. Nakai, K. Muroga, and M. Sorimachi. 1991. A cell line derived from the fin of Japanese flounder, Paralichthys olivaceus. Gyobyo Kenkyu 26:61-75.

Nakajima, T., A. Nomoto, M. Matsuhashi, K. Miura, and M. Muramatsu. 1988. [New basic biochemical experiment method. IV: Assay method using bioactivity.] Maruzen Press, Tokyo, Japan. (In Japanese.)

Nicholson, B. L., D. J. Danner, and J. L. Wu. 1987. Three new continuous cell lines from marine fishes of Asia. In Vitro Cellular and Developmental Biology 23:199-204.

Ojima, Y. 1983. [Fish cytogenetics.] Suikousha, Tokyo. (In Japanese.)

Paul, J. 1972. Behavior of cells in culture: growth differentiation and metabolism. Pages 21-55 in Cell and tissue culture, 4 th edition. Churchill Livingstone, London.

Reed, J. L., and H. A. Muench. 1938. A simple method of estimating fifty percent end points. American Journal of Hygiene 27:493-497.

Tung, L. C., S. N. Chen, and G. H. Kou. 1991. Three cell lines derived from spleen and kidney of black porgy (Acanthopagrus schlegeli). Gyobyo Kenkyu 26:109-117.

Wakimoto, K., T. Tarumi, and Y. Tanaka. 1984. [Per- sonal computer handbook: statistical analysis. I. Basic statistics.] Kyouritsu Press, Tokyo. (In Japanese.)

Watanabe, Y., H. Hanada, and M. Ushiyama. 1981. Monolayer cell cultures from marine fishes. Fish Pathology 15:201-205.

Wen, C. M., S. N. Chen, and G. H. Kou. 1990. A cell line derived from jarbua (Therapan jarbua Forskal) fin. COA (Council of Agriculture) Fisheries Series 24:18-39.

Winton, J. R., C. N. Lannan, J. L. Fryer, and T. Kimura. 1981. Isolation of a new reovirus from chum salmon. Fish Pathology 15:155-162.

Wolf, K. 1988. Fish viruses and fish viral diseases. Cornell University Press, Ithaca, New York.

Wolf, K., and J. A. Mann. 1980. Poikilotherm vertebrate cell lines and viruses: a current listing for fishes. In Vitro (Rockville) 16:168-179.

Wolf, K., and M. C. Quimby. 1962. Established eurythermic line of fish cells in vitro. Science (Washington, D.C.) $135: 1065-1066$.

Wolf, K., and M. C. Quimby. 1969. Fish cell and tissue culture. Pages 253-303 in W. S. Hoar and D. J. Randall, editors. Fish physiology, volume 3. Academic Press, New York.

Wolf, K., and M. C. Quimby. 1976. Primary monolayer culture of fish cells initiated from trypsinized tissues. Procedure 41541. Tissue Culture Manual 2:453-456.

Yoshimizu, M., M. Kamei, S. Dirakbusarakom, and T. Kimura. 1988. Fish cell lines: susceptibility to salmonid viruses. Pages 207-210 in Y. Kuroda, E. Kurstak, and K. Maramorosch, editors. Invertebrate and fish tissue culture. Japan Scientific Societies Press, Tokyo. (Also Springer-Verlag, Berlin.)

Yoshimizu, M., T. Nomura, T. Awakura, Y. Ezura, and T. Kimura. 1989. Prevalence of pathogenic fish viruses in anadromous masu salmon (Oncorhynchus masou) in the northern part of Japan, 19761987. Physiology and Ecology Japan (Special Volume) 1:559-576. 